\title{
mRNA profiling of the cancer degradome in oesophago-gastric adenocarcinoma
}

\author{
JP Baren ${ }^{1,5}$, GD Stewart ${ }^{1,2,5}$, A Stokes ${ }^{3}, K_{\text {Gray }^{3}}$, CJ Pennington ${ }^{3}$, R O'Neill ${ }^{4}$, DAC Deans ${ }^{1,4}$, \\ S Paterson-Brown ${ }^{4}$, ACP Riddick ${ }^{2}$, DR Edwards ${ }^{3}$, KCH Fearon', JA Ross ${ }^{1,6}$ and RJE Skipworth ${ }^{*, 1,4,6}$ \\ 'Tissue Injury and Repair Group, Clinical and Surgical Sciences, University of Edinburgh-MRC Centre for Regenerative Medicine, Royal Infirmary \\ of Edinburgh, 51 Little France Crescent, Edinburgh, UK; ${ }^{2}$ Edinburgh Urological Cancer Group, Western General Hospital, Edinburgh EH4 2XU, UK; \\ ${ }^{3}$ School of Biological Sciences, University of East Anglia, Norwich, UK; ${ }^{4}$ Department of Surgery, Royal Infirmary of Edinburgh, Edinburgh, UK
}

\begin{abstract}
BACKGROUND: Degradation of the extracellular matrix is fundamental to tumour development, invasion and metastasis. Several protease families have been implicated in the development of a broad range of tumour types, including oesophago-gastric $(\mathrm{OG})$ adenocarcinoma. The aim of this study was to analyse the expression levels of all core members of the cancer degradome in OG adenocarcinoma and to investigate the relationship between expression levels and tumour/patient variables associated with poor prognosis.

METHODS: Comprehensive expression profiling of the protease families (matrix metalloproteinases (MMPs), members of the ADAM metalloproteinase-disintegrin family (ADAMs)), their inhibitors (tissue inhibitors of metalloproteinase), and molecules involved in the c-Met signalling pathway, was performed using quantitative real-time reverse transcription polymerase chain reaction in a cohort of matched malignant and benign peri-tumoural OG tissue $(n=25$ patients). Data were analysed with respect to clinico-pathological variables (tumour stage and grade, age, sex and pre-operative plasma C-reactive protein level).

RESULTS: Gene expression of MMPI, 3, 7, 9, 10, 11, 12, 16 and 24 was upregulated by factors $>4$-fold in OG adenocarcinoma samples compared with matched benign tissue $(P<0.01)$. Expression of ADAM8 and ADAMI 5 correlated significantly with tumour stage $(P=0.048$ and $P=0.044)$, and ADAMI 2 expression correlated with tumour grade $(P=0.0 \mathrm{I} I)$.

CONCLUSION: This study represents the first comprehensive quantitative analysis of the expression of proteases and their inhibitors in human $O G$ adenocarcinoma. These findings implicate elevated ADAM8, 12 and 15 mRNA expression as potential prognostic molecular markers.

British Journal of Cancer (2012) 107, |43-149. doi: I0.1038/bjc.2012.239 www.bjcancer.com
\end{abstract}

Published online 7 June 2012

(C) 2012 Cancer Research UK

Keywords: MMPs; ADAMs; degradome; gastric cancer; oesophageal cancer; adenocarcinoma

Oesophageal and junctional adenocarcinomas continue to increase in incidence and gastric adenocarcinoma remains the fourth commonest form of cancer worldwide (Pera, 2003). Oesophago-gastric (OG) adenocarcinoma causes more than a million deaths per annum (Parkin et al, 2005). Survival is generally poor with 5-year survival rates in the United Kingdom of $13 \%$ and $7.5 \%$ for gastric and oesophageal cancer, respectively (Quinn, 2003). The identification of biomarkers for diagnosis, treatment and prognosis is therefore an unmet clinical need that requires urgent attention.

Degradation of the extracellular matrix (ECM) is fundamental to tumour development and invasion (Egeblad and Werb, 2002; Roy et al, 2009; Kessenbrock et al, 2010), and evidence suggests that multiple ECM proteases and their inhibitors are mediators of OG tumourigenesis (Egeblad and Werb, 2002; Skrzydlewska et al, 2005; Kessenbrock et al, 2010). Furthermore, it has become evident that the function of proteases is more complex than believed initially

\footnotetext{
*Correspondence: Dr RJE Skipworth; E-mail: richard.skipworth@ed.ac.uk

${ }^{5}$ These authors contributed equally to this work.

${ }^{6}$ These authors are joint senior authors.

Revised 20 March 2012; accepted 25 April 20I2; published online 7 June 2012
}

(Kessenbrock et al, 2010) and, in addition to breaking down physical barriers, they may also play crucial roles in angiogenesis, apoptosis, cell migration and shedding of surface adhesion molecules (Egeblad and Werb, 2002). Examples of such enzyme systems include the matrix metalloproteinases (MMPs), their endogenous inhibitors (the tissue inhibitors of metalloproteinases (TIMPs) (Bourboulia and Stetler-Stevenson, 2010)), and the ADAM (A Disintegrin And Metalloproteinase) family. Matrix metalloproteinases are a subfamily of zinc-dependent endopeptidases consisting of 24 members divided into five main groups according to their structure and substrate specificity: collagenases, gelatinases, membrane type, stromelysins and matrilysins (Egeblad and Werb, 2002; Bourboulia and Stetler-Stevenson, 2010; Kessenbrock et al, 2010). Most MMPs are secreted into plasma and are inhibited by $\alpha_{2}$-macroglobulin secreted by the liver (Bourboulia and Stetler-Stevenson, 2010). The MMPs are regulated by the four members of the TIMP family, which each bind reversibly to MMPs with some specificity; for example, TIMP1 binds preferentially to MMP1, 3, 7 and 9 and is a relatively poor inhibitor of membrane-type MMPs (Baker et al, 2002; Bourboulia and Stetler-Stevenson, 2010). The 21 members of the human ADAM family are transmembrane and secreted metalloproteinases that are relatives of the MMPs, as both families belong to the 
metzincin superfamily (Edwards et al, 2008; Rocks et al, 2008; Duffy et al, 2009). In addition to proteolysis, the ADAMs have roles in cell adhesion mediated by interaction of their disintegrin and Cys-rich domains with integrins and other receptors (Rocks et al, 2008; Duffy et al, 2009). Approximately $50 \%$ of ADAMs contain the catalytic consensus sequence HEXXH in their protease domain (Duffy et al, 2009), and it is thought that only these ADAMs possess protease activity (Duffy et al, 2009). The activity of selected ADAMs can also be inhibited by certain TIMPs, principally TIMP3 (Amour et al, 1998, 2000; Kashiwagi et al, 2001). There is some evidence supporting a role for the earliest identified proteases (MMP2, 7, 9 and TIMP1, 2) in the development of OG cancer (Rocks et al, 2008; Bourboulia and Stetler-Stevenson, 2010) but little is known about the role of more recently discovered MMPs, TIMPs or ADAMs (Rocks et al, 2008; Duffy et al, 2009). Most studies have used immunohistological methods to assess protease expression, and some have identified correlations with tumour progression and clinical outcome (Brown, 1998; Duffy et al, 2009; Bourboulia and Stetler-Stevenson, 2010). However, diverse techniques and a lack of reliable anti-protease antibodies have contributed to some contradictory observations (Bourboulia and Stetler-Stevenson, 2010).

An additional pathway hypothesised to play a role in the expression of ECM-degrading proteases during malignancy is the c-Met signalling pathway (Peruzzi and Bottaro, 2006; Gentile et al, 2008). On binding to the tyrosine kinase Met cell surface receptor, hepatocyte growth factor (HGF) activates a programme of cell dissociation and motility coupled with increased protease production, promoting cellular invasion and metastasis (Birchmeier et al, 2003). At present, however, there are little data regarding the role of the c-Met pathway in OG tumourigenesis.

In the present study, we aimed to investigate the expression of the entire MMP and TIMP families, a subset of the ADAMs, and the c-Met signalling pathway, in a cohort of samples of matched malignant and benign peri-tumoural OG tissue, using quantitative real-time polymerase chain reaction (PCR). Furthermore, we aimed to investigate the relationship between gene expression levels and tumour/patient variables associated with poor prognosis, including age, sex, tumour grade, stage and plasma C-reactive protein (CRP) concentration (Skipworth et al, 2010).

\section{MATERIALS AND METHODS}

\section{Study patients}

Patients with a histological diagnosis of OG adenocarcinoma undergoing surgical resection with curative intent $(n=25)$ were recruited. Patients were staged according to the AJCC/International Union Against Cancer (Sobin and Wittekind, 2002) (UICC) criteria before surgical resection. All patients provided written informed consent and the study was approved by the Lothian Research Ethics Committee.

\section{Tissue collection}

A Consultant Pathologist dissected matched samples of tumour tissue and peri-tumoural normal tissue from the resected specimens within 20 min of the blood supply of the resection specimen being interrupted. Samples were frozen immediately in liquid nitrogen using liquid nitrogen-resistant tubes (Corning BV, Amsterdam, The Netherlands), and stored at $-80^{\circ} \mathrm{C}$ until analysis.

\section{RNA extraction and reverse transcription}

Total RNA was isolated from the tissue samples by homogenisation in RNA Bee (Biogenesis Ltd, Poole, UK) using the TissueLyser (Quiagen, Crawley, UK) followed by the SV Total RNA isolation kit as described previously (Porter et al, 2004; Riddick et al, 2005). The RNA quality and concentration were determined using the
NanoDrop ND-1000 UV-Vis spectrophotometer (Labtech, Ringmer, UK). Total RNA $(1 \mu \mathrm{g})$ was reverse transcribed with $2 \mu \mathrm{g}$ random hexamers (Amersham Pharmacia Biotech, Little Chalfont, UK) and 200 units of SuperScript II reverse transcriptase (Invitrogen, Cambridge, UK) according to the manufacturer's instructions using a GRI DNA Engine (GRI Ltd, Braintree, UK). The cDNA was diluted 1:100 with PCR grade water and stored at $-20^{\circ} \mathrm{C}$.

\section{Quantitative real-time PCR}

Specific primers and probes for selected human MMPs, TIMPs, ADAMs, c-Met and HGF were designed as detailed previously (Nuttall et al, 2003; Porter et al, 2004; Riddick et al, 2005). The $18 \mathrm{~S}$ ribosomal RNA (rRNA) was used as an endogenous control to normalise for differences in the amount of total RNA in each sample, using previously validated procedures (Wall and Edwards, 2002). Polymerase chain reaction reactions were carried out as described previously (Nuttall et al, 2003) using the ABI 7700 real-time PCR machine (Applied Biosystems, Carlsbad, CA, USA) with each reaction containing $5 \mathrm{ng}$ of reverse-transcribed RNA (1 ng for 18S) in a $25-\mu$ l reaction. The RNA levels (compared with $18 \mathrm{~S}$ rRNA) in each sample were determined by performing standard curves for all target genes covering $1-0.0625 \mathrm{ng}$ of RNA for $18 \mathrm{~S}$ and $20-0.5 \mathrm{ng}$ RNA for all other genes. Genes with cycle threshold $\left(C_{\mathrm{T}}\right)$ of 40 were excluded from the analysis as there was no PCR amplification.

\section{Assessment of plasma CRP concentration}

Plasma CRP was assayed using automated methods on an Olympus AU2700 analyser (Olympus Diagnostica GmbH (Irish Branch), Lismeehan, Ireland), in the Department of Clinical Chemistry, Royal Infirmary of Edinburgh (fully accredited by Clinical Pathology Accreditation (UK) Ltd). Appropriate internal quality controls were included, with CVs typically $3.4 \%$ at concentrations $<15 \mathrm{mgl}^{-1}$ and $1.6 \%$ at $80 \mathrm{mgl}^{-1}$.

\section{Statistical analysis}

All statistical analyses were performed using Statistical Package for Social Services version 17 (SPSS, Chicago, IL, USA) and GraphPad Prism version 5 (GraphPad Software Inc., La Jolla, CA, USA). Malignant gene expression is expressed as a relative level compared with gene expression in matched benign peri-tumoural samples. Matched-pair analysis was performed using the Wilcoxon signed-rank test, whereas non-parametric comparisons were performed using the Mann-Whitney $U$-test and Kruskall-Wallis test. Correlation analysis was performed using Spearman's Rank Correlation Coefficient. Box-and-whisker plots of the gene expression levels (relative to $18 \mathrm{~S}$ rRNA) in malignant compared with benign OG tissue are also shown. Statistical significance was set at $P<0.05$.

\section{RESULTS}

\section{Study patients}

The median age of the recruited patients $(n=25)$ was 64 years, and $19(76 \%)$ patients were male. Primary tumour sites were oesophageal $(n=16,64 \%)$ and gastric $(n=9,36 \%)$. Histological tumour subtype was adenocarcinoma in all cases. A summary of patient demographics is shown in Table 1.

\section{Protease expression in matched malignant and benign OG tissue samples}

Expression data for all protease and inhibitor genes are summarised in Table 2. In total, expression levels of 13 different MMPs, 2 TIMPs, 6 ADAMs, c-Met and HGF were upregulated significantly in malignant $O G$ tissue compared with matched 
Table I Demographics of the patients recruited with oesophago-gastric cancer $(n=25)$

\begin{tabular}{lr}
\hline Characteristic & $\boldsymbol{n}$ (\%) \\
\hline Age (years) & $5(20)$ \\
$<60$ & $12(48)$ \\
$60-69$ & $8(32)$ \\
$\geqslant 70$ & \\
Sex & $19(76)$ \\
Male & $6(24)$ \\
Female & \\
Tumour site & $16(64)$ \\
Oesophageal & $9(36)$ \\
Gastric & \\
Histology & $25(100)$ \\
Adenocarcinoma & \\
UICC stage & $10(40)$ \\
I & $7(28)$ \\
II & $4(16)$ \\
III & $4(16)$ \\
IV & \\
Tumour grade & \\
Well differentiated & $2(8)$ \\
Moderately differentiated & $8(32)$ \\
Poorly differentiated & $15(60)$ \\
\hline
\end{tabular}

Abbreviation: UICC $=$ International Union Against Cancer. Tumour stage and grade were determined during routine histopathological examination.

benign peri-tumoural tissue (Table 2). Genes with the greatest relative increase in expression in malignant tissue were MMP1, 3, $7,9,10,11,12,16$ and $24(P<0.01)$, each of which demonstrated a median relative gene expression $>4$-fold than that of matched benign samples. Comparative box-and-whisker plots of finite gene expression levels compared with $18 \mathrm{~S}$ rRNA are shown in Figure 1 and Supplementary Figures 1 and 2. The protease with the largest relative increase in expression was MMP11, which had a median expression in malignant $O G$ tissue 28 times than that of benign tissue $(P<0.001)$ (Table 2; Figure 1).

\section{Relationship between gene expression and clinico-pathological variables}

Although ADAM8 and ADAM15 expression levels were only $\sim 1.5$ times that observed in benign tissue, expression levels increased significantly with worsening tumour stage $(P=0.048$ and $P=0.044$, respectively) (Table 3; Figure 2A and B). The ADAM12 expression also increased significantly with worsening tumour grade $(P=0.011)$ (Table 3; Figure 2C). Matrix metalloproteinase 19 expression in malignant tissue was significantly greater in women than men $(P=0.015)$ (Table 3$)$. No significant relationships were demonstrated between relative mRNA expression and preoperative plasma CRP level or patient age.

\section{DISCUSSION}

The ECM is a complex structure consisting of many different proteins, and thus its degradation requires a combination of proteases (Bourboulia and Stetler-Stevenson, 2010). In order to understand the complex processes underpinning tumour development and invasion, it is important to study the complete range of proteases that may be responsible. This study is the first comprehensive analysis of the expression of the MMP, TIMP and ADAM families in a series of human OG adenocarcinoma samples.
Table 2 Relative gene expression in malignant oesophago-gastric tissue compared with matched benign samples

\begin{tabular}{|c|c|c|}
\hline Gene & $\begin{array}{l}\text { Relative upregulation of gene } \\
\text { expression in malignant tissue }\end{array}$ & $P$-value \\
\hline MMPI & 8.04 & $<0.001$ \\
\hline MMP2 & 1.21 & 0.230 \\
\hline MMP3 & 8.25 & $<0.001$ \\
\hline MMP7 & 19.83 & $<0.001$ \\
\hline MMP8 & ND & ND \\
\hline MMPQ & 6.23 & $<0.01$ \\
\hline MMPIO & 15.46 & $<0.001$ \\
\hline MMPII & 20.18 & $<0.001$ \\
\hline$M M P I 2$ & 18.56 & $<0.001$ \\
\hline MMPI3 & 0.48 & 0.855 \\
\hline MMP/4 & 3.65 & $<0.001$ \\
\hline MMPI5 & 0.92 & 0.458 \\
\hline MMPI6 & 8.86 & $<0.01$ \\
\hline MMPI7 & 5.46 & 0.117 \\
\hline MMPI9 & 1.43 & $<0.05$ \\
\hline MMP2O & ND & ND \\
\hline MMP2I & ND & ND \\
\hline MMP23 & 1.31 & $<0.05$ \\
\hline MMP24 & 5.76 & $<0.01$ \\
\hline MMP25 & 3.30 & $<0.05$ \\
\hline MMP26 & ND & ND \\
\hline MMP27 & 1.21 & 0.528 \\
\hline MMP28 & 2.42 & 0.277 \\
\hline TIMPI & 2.59 & $<0.001$ \\
\hline TIMP2 & 1.78 & 0.170 \\
\hline TIMP3 & 1.54 & $<0.05$ \\
\hline TIMP4 & 5.02 & 0.0657 \\
\hline ADAM8 & 1.54 & $<0.01$ \\
\hline ADAM9 & 1.88 & $<0.01$ \\
\hline ADAMIO & 1.67 & $<0.00$ \\
\hline ADAM 12 & 3.79 & $<0.01$ \\
\hline ADAM 15 & 1.46 & $<0.01$ \\
\hline ADAM 17 & 2.47 & $<0.00$ \\
\hline ADAM 19 & 1.58 & 0.0534 \\
\hline ADAM28 & 0.75 & 0.291 \\
\hline c-Met & 4.11 & $<0.01$ \\
\hline HGF & 2.63 & $<0.01$ \\
\hline
\end{tabular}

Abbreviations: $\mathrm{ND}=$ not detected; $\mathrm{MMP}=$ matrix metalloproteinase; $\mathrm{TIMP}=$ tissue inhibitors of metalloproteinase; $A D A M=a$ disintegrin and metalloproteinase; $H G F=$ hepatocyte growth factor. Relative gene expression was upregulated in malignant tissue for the majority of proteases. Relative upregulation of mRNA was determined by calculating the median difference in expression between malignant and matched benign samples. Data were compared using Wilcoxon signed-rank test.

The expression of many MMPs was increased significantly in OG cancer, particularly MMPs 1, 3, 7, 10, 11, 12 and 24 (Table 2; Figure 1). The general upregulation of MMPs is consistent with the concept that tumourigenesis involves the synergistic action of multiple proteases, causing cell migration, angiogenesis and modulating cell biology (Kessenbrock et al, 2010).

The protease MMP7 has been the most widely investigated in previous studies of OG cancer. Increased MMP7 mRNA expression has been shown in gastric adenocarcinoma (Honda et al, 1996), whereas elevated MMP7 protein expression has been shown in both gastric (Honda et al, 1996; Kitoh et al, 2004; Kubben et al, 2006) and oesophageal (Tanioka et al, 2003) malignancies. The suggested pro-tumourigenic mechanisms of MMP7 may involve protease activation by Helicobacter pylori (Wroblewski et al, 2003), and cleavage of the membrane-bound epithelial transmembrane adhesion molecule E-cadherin, the release of which promotes cell invasion by disrupting cell-cell contacts (Noe et al, 2001). In-vitro studies using a gastric cancer cell line have also demonstrated that MMP7 production is increased by HGF, indicating a role for the 

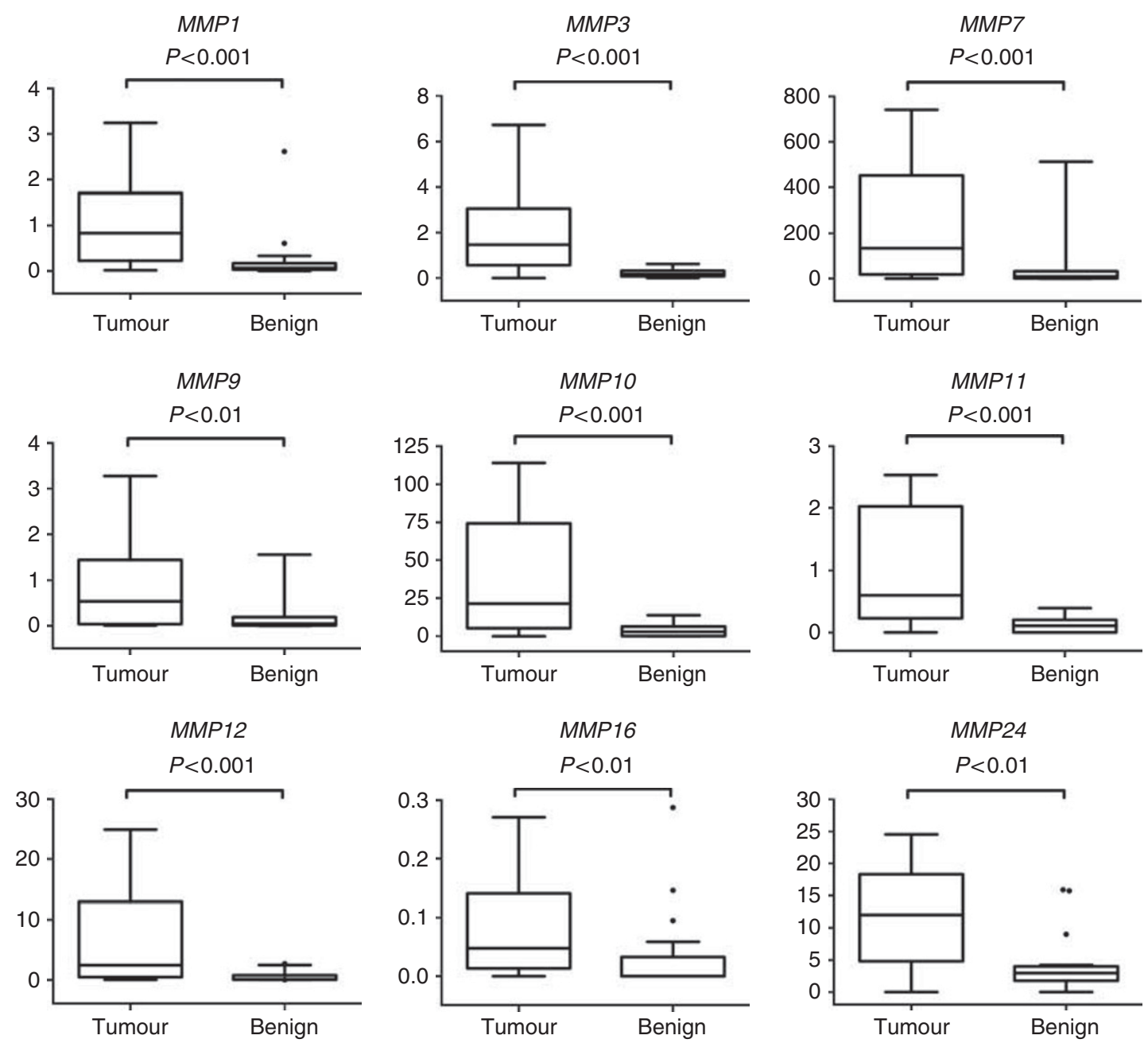

Figure I Box-and-whisker plots of the gene expression (relative to I8S rRNA) of the most highly expressed degradome components in malignant compared with benign $O G$ tissue $(P<0.01)$. Y-axes show relative mRNA expression compared with I $8 \mathrm{~S} r R N A$ expression ( $y$-axes limited for visual clarity). Each of these degradome components was expressed in malignant tissue at levels $>4$-fold that are seen in benign tissue (range 3.65-20.18). Data were compared using Wilcoxon signed-rank test. $\mathbf{O}=$ Outlier (value $>1.5$ times the interquartile range beyond the quartiles).

Table 3 Relationship between relative gene expression in malignant oesophago-gastric tissue and clinico-pathological parameters

\begin{tabular}{llc}
\hline Gene & Clinico-pathological variable & P-value \\
\hline ADAM8 & Tumour stage & 0.048 \\
ADAMI5 & Tumour stage & 0.044 \\
ADAMI2 & Tumour grade & 0.011 \\
MMPI9 & Gender & 0.015 \\
\hline
\end{tabular}

Abbreviations: $\mathrm{ADAM}=$ a disintegrin and metalloproteinase; $\mathrm{MMP}=$ matrix metalloproteinase: $\mathrm{PCR}=$ polymerase chain reaction. Statistical analysis was completed using Kruskal-Wallis tests to investigate the relationship between protease expression and tumour stage and grade, and a Mann-Whitney U-test for relationships between gene expression and gender. Samples with a $C_{T}$ value of 40 denoting no PCR amplification were excluded before statistical analysis. Values are given to three decimal places.

c-Met signalling pathway in the pathogenesis of OG cancer (Lee et al, 2007), a concept that is supported by the increased malignant expression of HGF and c-Met in the present study.

Of the proteases that were highly upregulated in the present study, MMP1, 3, 7, 10 and 12 are located in a cluster on chromosome 11q22.3 (Jackson et al, 2010), raising the possibility of co-ordinated expression of these genes. Immunohistochemistry has demonstrated increased MMP1 (Inoue et al, 1999), MMP10 (Aung et al, 2006), MMP11 (Zhao et al, 2010) and MMP12 (Salmela et al, 2001) expression in gastric adenocarcinoma, whereas MMP3 is associated with increased risk of oesophageal adenocarcinoma (Bradbury et al, 2009). These MMPs share similar promoter conformation, with TATA boxes at around $-30 \mathrm{bp}$ and activator protein-1 transcription factor sites around $-70 \mathrm{bp}$ (Clark et al, 2008). It has been suggested that these MMPs can be co-regulated by a variety of chemical stimuli, including IL-1 and TNF- $\alpha$ (Clark et al, 2008).

The MMP with the greatest upregulation in the present study is MMP11 (Table 2), with a $\sim 20$-fold increase in expression in malignant compared with matched benign OG tissue. Zhao et al (2010) have shown using RT-PCR that MMP11 expression is elevated in gastric adenocarcinoma and correlated with TNM stage. Unlike other members of the MMP family, MMP11 does not degrade classical ECM proteins and instead facilitates the breakdown of the serine protease inhibitors $\alpha_{1}$-antitrypsin and insulinlike growth factor binding protein-1 (IGFBP-1) (Nedic et al, 2007). Insulin-like growth factor-1 inhibits malignant cell apoptosis through a paracrine mechanism (Zhao et al, 2010); thus IGFBP-1 proteolysis leads to the release of IGF-1, inhibited apoptosis, and the progression to a more invasive stage of malignancy (Kasper et al, 2007). 
A

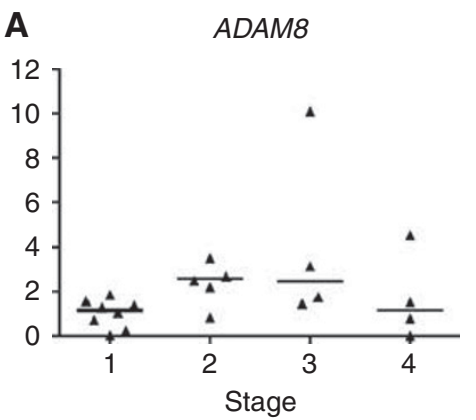

B

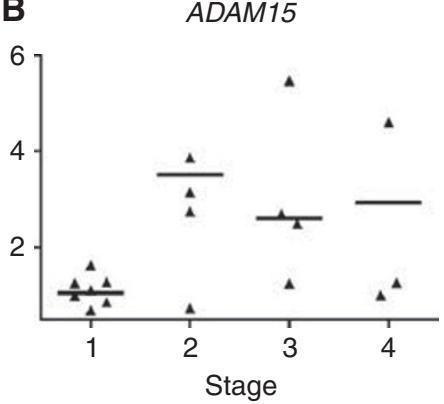

C

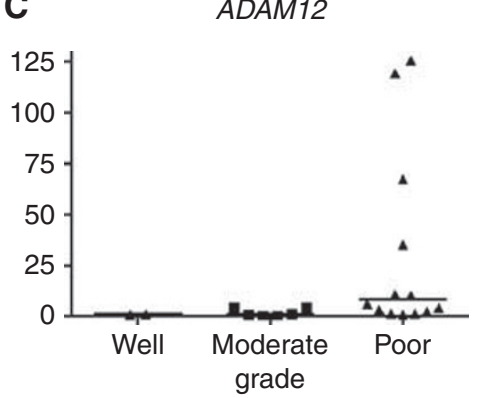

Figure 2 Relationship between relative gene expression and tumour stage and grade. (A) ADAM8 expression associated positively with tumour stage $(P=0.048)$. (B) ADAMI5 expression associated positively with tumour stage $(P=0.044)$. (C) ADAMI2 expression associated positively with worsening tumour grade $(P=0.0 \mathrm{II})$. Horizontal bars show median values. Comparisons were performed using Kruskal-Wallis test. Extreme values are not shown for visual clarity.

Of the remaining MMPs, expression of the gelatinases MMP2 and MMP9 has been shown to be elevated in OG adenocarcinoma (Sier et al, 1996; Murray et al, 1998; Parsons et al, 1998; Shim et al, 2007; Sampieri et al, 2010). In the present study, MMP9 levels were increased $\sim 2$-fold in malignant OG tissue compared with benign, but MMP2 expression was not significantly different, mirroring work by Sampieri et al (2010). Tissue inhibitors of metalloproteinase 3, which was elevated in malignant tissue in the current study, may indirectly influence the expression of MMP2 (Bourboulia and Stetler-Stevenson, 2010), and thus it is possible that high TIMP3 expression was the cause of the lower MMP2 expression observed.

Tissue inhibitors of metalloproteinases are key regulators of MMPs, and have an important role in tumourigenesis (Mimori et al, 1997; Brew and Nagase, 2010). Our data show that the expression of TIMP1 and 3 were elevated in OG adenocarcinoma. Classically, it was thought that TIMPs protected against malignancy by inhibiting the proteases responsible for ECM degradation (Bourboulia and Stetler-Stevenson, 2010), and studies in various cancers have shown reduced expression (Ko et al, 1998; Riddick et al, 2005). Gu et al (2008) demonstrated downregulation of TIMP3 in OG adenocarcinoma and suggested that TIMP3 acts as a tumour suppressor, inhibiting growth, angiogenesis and invasion. However, other researchers have revealed increased TIMP expression in malignancy (Joo et al, 2000; Shim et al, 2007; Brew and Nagase, 2010), including oesophageal cancer (Salmela et al, 2001). Tissue inhibitors of metalloproteinase 3 is proposed to induce apoptosis through inhibition of ADAM17 (TNF- $\alpha$ converting enzyme), with subsequent stabilisation of TNF receptors (Brew and Nagase, 2010), supporting the results of this study. The present study also supports previous investigations that have demonstrated elevated TIMP1 expression in gastric cancer (Mimori et al, 1997; Murray et al, 1998; Joo et al, 2000). Possible mechanisms of action for TIMP1 in tumourigenesis involve a combination of cell-cycle arrest and anti-apoptotic activity, leading to cellular transformation and invasion (Brew and Nagase, 2010).

The expression levels of the majority of the profiled ADAMs, namely ADAM8, 9, 10, 12, 15 and 17, were increased significantly in malignant OG tissue compared with matched benign samples (Table 2). The ADAM12 demonstrated the highest expression levels with a relative increase of $\sim 4$-fold in malignant tissue (Figure 2). Previous studies have shown that various members of the ADAM family are increased in several cancer types, including lung, brain and prostate (Rocks et al, 2008; Duffy et al, 2009), but few have investigated the role in OG malignancy. The present study supports the work of Carl-McGrath et al (2005), who used RT-PCR to show that ADAM9, 12 and 15 expression is elevated in malignant compared with matched benign gastric tissue. The authors suggested that these proteases are involved in malignant transformation via the proteolytic shedding of signalling molecules and the consequent transactivation of their receptors, such as the epithelial growth factor receptor and its ligands (Carl-McGrath et al, 2005). Yoshimura et al (2002) demonstrated upregulation of ADAM10 and ADAM17, but not ADAM15, in antral gastric tissue during Helicobacter pylori infection, suggesting that their expression is upregulated by the bacteria. Furthermore, it is believed that ADAM17 is important for the release of active TNF- $\alpha$, a pro-inflammatory cytokine involved in cancer development via mucosal inflammation and damage (Yoshimura et al, 2002).

Expression of ADAM8 and ADAM15 in malignant OG adenocarcinoma correlated with increasing tumour stage, and ADAM12 expression correlated with tumour grade (Figure 2), implying that these proteases are potential prognostic markers of OG adenocarcinoma. The ADAM8 expression has been shown to correlate significantly with poor prognostic parameters in prostate (Fritzsche et al, 2006) and brain (Wildeboer et al, 2006) tumours. However, this is the first study to report ADAM8 expression in OG malignancy. The ADAM15 is located on chromosome 1 at $1 \mathrm{q} 21.3$ (Kuefer et al, 2006), a region known to be amplified in several types of adenocarcinoma (Glinksy et al, 2003). The ADAM15 digests collagen IV and gelatin and is involved in the promotion of cell growth (Mochizuki and Okada, 2007). It has shown to be expressed significantly in gastric adenocarcinoma (Carl-McGrath et al, 2005), and correlation with tumour stage has been demonstrated in breast and prostate cancer (Keufer et al, 2006). Figure 2 suggests that the expression of ADAM8 and ADAM15 in stage 4 cancers declines to stage 1 levels. Stage 4 disease is associated with distant (or at least significant nodal) metastases, and therefore ADAM8 and 15 levels may be reduced at this time in order to allow the dissociation of tumour cell adhesion and the process of metastasis. Whether this decline in expression reflects a causative initiator of metastasis or simply a small component of an overall metastatic phenomenon remains unclear. Further studies are required to verify this finding in other patient groups.

A similar link between ADAM12 expression and tumour grade has been demonstrated previously in malignancies of other tissues (Kveiborg et al, 2008; Duffy et al, 2009). Frohlich et al (2006) showed that the level of ADAM12 mRNA and protein expression in bladder tumour tissue samples correlated with the tumour grade. Interestingly, the concentration of ADAM12 in the urine of patients with bladder cancer was significantly elevated compared with healthy patients (Frohlich et al, 2006), suggesting that ADAM12 may be secreted by malignant tissue. Furthermore, Roy et al (2004) have also established a positive correlation between urinary ADAM12 levels and breast cancer progression. Thus, patient urine and possibly plasma may be potential biomarker sources in patients with OG cancer.

In conclusion, this study provides the most detailed profile to date of the degradome in OG malignancy. It implicates 
several MMPs, TIMPs, ADAMs and the c-Met signalling pathway in OG tumourigenesis. Larger clinical studies are required to assess the potential predictive and prognostic nature of these RNAs. Studies of both protein expression and function are required to identify if these proteins may represent novel therapeutic targets. However, such studies may be hampered by the unreliability of anti-protease antibodies.

\section{REFERENCES}

Amour A, Knight CG, Webster A, Slocombe PM, Stephens PE, Knauper V, Docherty AJ, Murphy G (2000) The in vitro activity of ADAM-10 is inhibited by TIMP-1 and TIMP-3. FEBS Lett 473(3): 275-9

Amour A, Slocombe PM, Webster A, Butler M, Knight CG, Smith BJ, Stephens PE, Shelley C, Hutton M, Knauper V, Docherty AJ, Murphy G (1998) TNF-alpha converting enzyme (TACE) is inhibited by TIMP-3. FEBS Lett 435(1): 39-44

Aung PP, Oue N, Mitani Y, Nakayama H, Yoshida K, Noguchi T, Bosserhoff AK, Yasui W (2006) Systematic search for gastric cancerspecific genes based on SAGE data: melanoma inhibitory activity and matrix metalloproteinase-10 are novel prognostic factors in patients with gastric cancer. Oncogene 25(17): 2546-2557

Baker AH, Edwards DR, Murphy G (2002) Metalloproteinase inhibitors: biological actions and therapeutic opportunities. J Cell Sci 115(Part 19): 3719-3727

Birchmeier C, Birchmeier W, Gherardi E, Vande Woude GF (2003) Met, metastasis, motility and more. Nat Rev Mol Cell Biol 4(12): 915-925

Bourboulia D, Stetler-Stevenson WG (2010) Matrix metalloproteinases (MMPs) and tissue inhibitors of metalloproteinases (TIMPs): Positive and negative regulators in tumor cell adhesion. Semin Cancer Biol 20(3): 161-168

Bradbury PA, Zhai R, Hopkins J, Kulke MH, Heist RS, Singh S, Zhou W, Ma C, Xu W, Asomaning K, Ter-Minassian M, Wang Z, Su L, Christiani DC, Liu G (2009) Matrix metalloproteinase 1, 3 and 12 polymorphisms and esophageal adenocarcinoma risk and prognosis. Carcinogenesis 30(5): 793-798

Brew K, Nagase H (2010) The tissue inhibitors of metalloproteinases (TIMPs): an ancient family with structural and functional diversity. Biochim Biophys Acta 1803(1): 55-71

Brown PD (1998) Matrix metalloproteinases in gastrointestinal cancer. Gut 43(2): 161-163

Carl-McGrath S, Lendeckel U, Ebert M, Roessner A, Rocken C (2005) The disintegrin-metalloproteinases ADAM9, ADAM12, and ADAM15 are upregulated in gastric cancer. Int J Oncol 26(1): 17-28

Clark IM, Swingler TE, Sampieri CL, Edwards DR (2008) The regulation of matrix metalloproteinases and their inhibitors. Int J Biochem Cell Biol 40(6-7): 1362-1378

Duffy MJ, McKiernan E, O'Donovan N, McGowan PM (2009) Role of ADAMs in cancer formation and progression. Clin Cancer Res 15(4): 1140-1144

Edwards DR, Handsley MM, Pennington CJ (2008) The ADAM metalloproteinases. Mol Aspects Med 29(5): 258-289

Egeblad M, Werb Z (2002) New functions for the matrix metalloproteinases in cancer progression. Nat Rev Cancer 2(3): 161-174

Fritzsche FR, Jung M, Xu C, Rabien A, Schicktanz H, Stephan C, Dietel M, Jung K, Kristiansen G (2006) ADAM8 expression in prostate cancer is associated with parameters of unfavorable prognosis. Virchows Archiv 449(6): 628-636

Frohlich C, Albrechtsen R, Dyrskjot L, Rudkjaer L, Orntoft TF, Wewer UM (2006) Molecular profiling of ADAM12 in human bladder cancer. Clin Cancer Res 12(24): 7359-7368

Gentile A, Trusolino L, Comoglio PM (2008) The Met tyrosine kinase receptor in development and cancer. Cancer Metastasis Rev 27(1): 85-94

Glinksy GV, Krones-Herzig A, Glinkkii AB (2003) Malignancy-associated regions of transcriptional activation: gene expression profiling identifies common chromosomal regions of a recurrent transcriptional activation in human prostate, breast, ovarian, and colon cancers. Neoplasia 5(3): $218-228$

Gu P, Xing X, Tanzer M, Rocken C, Weichert W, Ivanauskas A, Pross M, Peitz U, Malfertheiner P, Schmid RM, Ebert MP (2008) Frequent loss of TIMP-3 expression in progression of esophageal and gastric adenocarcinomas. Neoplasia 10(6): 563-572

\section{ACKNOWLEDGEMENTS}

We thank Dr Catharine Sturgeon of the Department of Clinical Chemistry, Royal Infirmary of Edinburgh, who performed the analysis of plasma C-reactive protein concentration.

Supplementary Information accompanies the paper on British Journal of Cancer website (http://www.nature.com/bjc)
Honda M, Mori M, Ueo H, Sugimachi K, Akiyoshi T (1996) Matrix metalloproteinase-7 expression in gastric carcinoma. Gut 39(3): 444-448 Inoue T, Yashiro M, Nishimura S, Maeda K, Sawada T, Ogawa Y, Sowa M, Chung KH (1999) Matrix metalloproteinase-1 expression is a prognostic factor for patients with advanced gastric cancer. Int J Mol Med 4(1): 73-77

Jackson BC, Nebert DW, Vasiliou V (2010) Update of human and mouse matrix metalloproteinase families. Hum Genomics 4(3): 194-201

Joo YE, Seo KS, Kim HS, Rew JS, Park CS, Kim SJ (2000) Expression of tissue inhibitors of metalloproteinases (TIMPs) in gastric cancer. Dig Dis Sci 45(1): 114-121

Kashiwagi M, Tortorella M, Nagase H, Brew K (2001) TIMP-3 is a potent inhibitor of aggrecanase 1 (ADAM-TS4) and aggrecanase 2 (ADAM-TS5). J Biol Chem 276(16): 12501-12504

Kasper G, Reule M, Tschirschmann M, Dankert N, Stout-Weider K, Lauster R, Schrock E, Mennerich D, Duda GN, Lehmann KE (2007) Stromelysin-3 over-expression enhances tumourigenesis in MCF-7 and MDA-MB-231 breast cancer cell lines: involvement of the IGF-1 signalling pathway. BMC Cancer 7: 12

Kessenbrock K, Plaks V, Werb Z (2010) Matrix metalloproteinases regulators of the tumor microenvironment. Cell 141(1): 52-67

Keufer R, Day K, Kleer C, Sabel M, Hofer M, Varambally S, Zorn C, Chinnaiyan A, Rubin M, Day M (2006) ADAM15 disintegrin is associated with aggressive prostate and breast cancer disease. Neoplasia 8(4): 319-329

Kitoh T, Yanai H, Saitoh Y, Nakamura Y, Matsubara Y, Kitoh H, Yoshida T, Okita K (2004) Increased expression of matrix metalloproteinase-7 in invasive early gastric cancer. J Gastroenterol 39(5): 434-440

Ko BK, Cho HR, Choi DW, Nam CW, Park CJ, Kim GY, Kim SS, Woo YJ, Huh J, Kim MY (1998) Reduced expression of tissue inhibitor of metalloproteinase in nodal metastasis of stomach cancer. J Korean Med Sci 13(3): 286-290

Kubben FJ, Sier CF, Meijer MJ, van den Berg M, van der Reijden JJ, Griffioen G, van de Velde CJ, Lamers CB, Verspaget HW (2006) Clinical impact of MMP and TIMP gene polymorphisms in gastric cancer. Br J Cancer 95(6): 744-751

Kuefer R, Day KC, Kleer CG, Sabel MS, Hofer MD, Varambally S, Zorn CS, Chinnaiyan AM, Rubin MA, Day ML (2006) ADAM15 disintigrin is associated with aggressive prostate and breast cancer disease. Neoplasia 8(4): 319-329

Kveiborg M, Albrechtsen R, Couchman JR, Wewer UM (2008) Cellular roles of ADAM12 in health and disease. Int J Biochem Cell Biol 40(9): 1685-1702

Lee KH, Choi EY, Hyun MS, Jang BI, Kim TN, Kim SW, Song SK, Kim JH, Kim JR (2007) Association of extracellular cleavage of E-cadherin mediated by MMP-7 with HGF-induced in vitro invasion in human stomach cancer cells. Eur Surg Res 39(4): 208-215

Mimori K, Mori M, Shiraishi T, Fujie T, Baba K, Haraguchi M, Abe R, Ueo H, Akiyoshi T (1997) Clinical significance of tissue inhibitor of metalloproteinase expression in gastric carcinoma. $\mathrm{Br} J$ Cancer 76(4): 531-536

Mochizuki S, Okada Y (2007) ADAMs in cancer cell proliferation and progression. Cancer Sci 98(5): 621-628

Murray GI, Duncan ME, Arbuckle E, Melvin WT, Fothergill JE (1998) Matrix metalloproteinases and their inhibitors in gastric cancer. Gut 43(6): 791-797

Nedic O, Malenkovic V, Nikolic JA, Baricevic I (2007) Insulin-like growth factor I (IGF-I) as a sensitive biomarker of catabolism in patients with gastrointestinal diseases. J Clin Lab Anal 21(5): 335-339

Noe V, Fingleton B, Jacobs K, Crawford HC, Vermeulen S, Steelant W, Bruyneel E, Matrisian LM, Mareel M (2001) Release of an invasion promoter E-cadherin fragment by matrilysin and stromelysin-1. J Cell Sci 114(Part 1): 111-118 
Nuttall RK, Pennington CJ, Taplin J, Wheal A, Yong VW, Forsyth PA, Edwards DR (2003) Elevated membrane-type matrix metalloproteinases in gliomas revealed by profiling proteases and inhibitors in human cancer cells. Mol Cancer Res 1(5): 333-345

Parkin DM, Bray F, Ferlay J, Pisani P (2005) Global cancer statistics, 2002. CA Cancer J Clin 55(2): 74-108

Parsons SL, Watson SA, Collins HM, Griffin NR, Clarke PA, Steele RJ (1998) Gelatinase (MMP-2 and -9) expression in gastrointestinal malignancy. Brit J Cancer 78(11): 1495-1502

Pera M (2003) Trends in incidence and prevalence of specialized intestinal metaplasia, barrett's esophagus, and adenocarcinoma of the gastroesophageal junction. World J Surg 27(9): 999-1008; discussion 1006-1008

Peruzzi B, Bottaro DP (2006) Targeting the c-Met signaling pathway in cancer. Clin Cancer Res 12(12): 3657-3660

Porter S, Scott SD, Sassoon EM, Williams MR, Jones JL, Girling AC, Ball RY, Edwards DR (2004) Dysregulated expression of adamalysin-thrombospondin genes in human breast carcinoma. Clin Cancer Res 10(7): 2429-2440

Quinn M (2003) Cancer Survival: England and Wales, 1991-2001, Twenty Major Cancers. National Office of Statistics: UK

Riddick AC, Shukla CJ, Pennington CJ, Bass R, Nuttall RK, Hogan A, Sethia KK, Ellis V, Collins AT, Maitland NJ, Ball RY, Edwards DR (2005) Identification of degradome components associated with prostate cancer progression by expression analysis of human prostatic tissues. Br J Cancer 92(12): 2171-2180

Rocks N, Paulissen G, El Hour M, Quesada F, Crahay C, Gueders M, Foidart JM, Noel A, Cataldo D (2008) Emerging roles of ADAM and ADAMTS metalloproteinases in cancer. Biochimie 90(2): 369-379

Roy R, Wewer UM, Zurakowski D, Pories SE, Moses MA (2004) ADAM 12 cleaves extracellular matrix proteins and correlates with cancer status and stage. J Biol Chem 279(49): 51323-51330

Roy R, Yang J, Moses MA (2009) Matrix metalloproteinases as novel biomarkers and potential therapeutic targets in human cancer. J Clin Oncol 27(31): 5287-5297

Salmela MT, Karjalainen-Lindsberg ML, Puolakkainen P, Saarialho-Kere U (2001) Upregulation and differential expression of matrilysin (MMP-7) and metalloelastase (MMP-12) and their inhibitors TIMP-1 and TIMP-3 in Barrett's oesophageal adenocarcinoma. Br J Cancer 85(3): 383-392

Sampieri CL, de la Pena S, Ochoa-Lara M, Zenteno-Cuevas R, LeonCordoba K (2010) Expression of matrix metalloproteinases 2 and 9 in human gastric cancer and superficial gastritis. World J Gastroenterol 16(12): 1500-1505

Shim KN, Jung SA, Joo YH, Yoo K (2007) Clinical significance of tissue levels of matrix metalloproteinases and tissue inhibitors of metalloproteinases in gastric cancer. J Gastroenterol 42(2): 120-128

Sier CF, Kubben FJ, Ganesh S, Heerding MM, Griffioen G, Hanemaaijer R, van Krieken JH, Lamers CB, Verspaget HW (1996) Tissue levels of matrix metalloproteinases MMP-2 and MMP-9 are related to the overall survival of patients with gastric carcinoma. Br J Cancer 74(3): 413-417

Skipworth RJ, Deans DA, Tan BH, Sangster K, Paterson-Brown S, Brown DA, Hunter M, Breit SN, Ross JA, Fearon KC (2010) Plasma MIC-1 correlates with systemic inflammation but is not an independent determinant of nutritional status or survival in oesophago-gastric cancer. Br J Cancer 102(4): 665-672

Skrzydlewska E, Sulkowska M, Koda M, Sulkowski S (2005) Proteolyticantiproteolytic balance and its regulation in carcinogenesis. World J Gastroenterol 11(9): 1251-1266

Sobin LH, Wittekind CH (2002) TNM Classification of Malignant Tumours. 6th edn. John Wiley: New York

Tanioka Y, Yoshida T, Yagawa T, Saiki Y, Takeo S, Harada T, Okazawa T, Yanai H, Okita K (2003) Matrix metalloproteinase-7 and matrix metalloproteinase-9 are associated with unfavourable prognosis in superficial oesophageal cancer. Br J Cancer 89(11): 2116-2121

Wall SJ, Edwards DR (2002) Quantitative reverse transcription-polymerase chain reaction (RT-PCR): a comparison of primer-dropping, competitive, and real-time RT-PCRs. Anal Biochem 300(2): 269-273

Wildeboer D, Naus S, Amy Sang Q, Bartsch J, Pagenstecher A (2006) Metalloproteinase disintegrins ADAM8 and ADAM19 are highly regulated in human primary brain tumors and their expression levels and activities are associated with invasiveness. J Neuropathol Exp Neurol 65: $516-527$

Wroblewski LE, Noble PJ, Pagliocca A, Pritchard DM, Hart CA, Campbell F, Dodson AR, Dockray GJ, Varro A (2003) Stimulation of MMP-7 (matrilysin) by Helicobacter pylori in human gastric epithelial cells: role in epithelial cell migration. J Cell Sci 116(Part 14): 3017-3026

Yoshimura T, Tomita T, Dixon MF, Axon AT, Robinson PA, Crabtree JE (2002) ADAMs (a disintegrin and metalloproteinase) messenger RNA expression in Helicobacter pylori-infected, normal, and neoplastic gastric mucosa. J Infect Dis 185(3): 332-340

Zhao ZS, Chu YQ, Ye ZY, Wang YY, Tao HQ (2010) Overexpression of matrix metalloproteinase 11 in human gastric carcinoma and its clinicopathologic significance. Hum Pathol 41(5): 686-696

This work is published under the standard license to publish agreement. After 12 months the work will become freely available and the license terms will switch to a Creative Commons Attribution-NonCommercial-Share Alike 3.0 Unported License. 